\title{
Perbandingan Tingkat Kecemasan Dalam Menghadapi Persalinan Pada Ibu Hamil Primigravida Dengan Multigravida Dimasa Pandemi Covid-19
}

\author{
Risnawati ${ }^{1}$ \\ Andi Nurlaily ${ }^{2}$ \\ Irmawati $^{3}$ \\ Ira Mayasari ${ }^{4}$ \\ Rusnawati ${ }^{5}$
}

Program Studi D-III Kebidanan, Stikes Panrita Husada Bulukumba, Indonesia, 1,2,3,4,5

\section{Alamat Korespondensi :}

Risnawati

Kebidanan

Stikes Panrita Husada Bulukumba

081241340778

Email: rhiesnaqueen@yahoo.co.id 


\begin{abstract}
ABSTRAK
Kehamilan merupakan peristiwa penting dan hal yang membahagiakan sekaligus menggelisahkan bagi seorang wanita. Kecemasan ini lazim terjadi pada ibu primigravida dikarenakan belum pernah melahirkan namun diera pandemic covid-19 dampak psikologis dan kekhawatiran terjadi pada ibu hamil yang akan emicu terjadinya kecemasan. Penelitian ini bertujuan untuk mengetahui perbandingan tingkat kecemasan dalam menghadapi persalinan pada ibu primigravida dengan multigravida trimester III kehamilan dan memberikan strategi dalam mengurangi kecemasan yakni Teknik pernafasan difragfma dimasa pandemic Covid-19. Metode yang digunakan dalam penelitian ini adalah analitik dengan jenis desain penelitian eksperimental quasi. Populasi dalam penelitian ini adalah ibu hamil trimester III di Puskesmas Bontobangun. Sampel dalam penelitian ini adalah ibu hamil trimester III(primigravida dan multigravida) berjumlah 25 orang. Hasil penelitian terdapat perbedaan rerata score derajat kecemasan bermakna pada kelompok intervensi dibandingkan kelompok control.
\end{abstract}

\title{
Kata Kunci : Kehamilan, Kecemasan, Primigravida,Multigravida,Covid-19
}

\begin{abstract}
Pregnancy is an important event and a happy and disturbing thing for a woman. This anxiety is common in primigravida mothers because they have never given birth, but in the era of the COVID-19 pandemic, psychological impacts and concerns occur in pregnant women which will trigger anxiety. This study aims to compare the level of anxiety in dealing with labor in primigravida mothers with multigravida in the third trimester of pregnancy and provide strategies to reduce anxiety, namely the diaphragmatic breathing technique during the Covid-19 pandemic. The method used in this research is analytic with a quasi-experimental research design. The population in this study were pregnant women in the third trimester at the Bontobangun Health Center. The sample in this study were 25 pregnant women in the third trimester (primigravida and multigravida). The results showed that there was a significant difference in the mean score of the degree of anxiety in the intervention group compared to the control group. Pregnancy is an important event and a happy and disturbing thing for a woman. This anxiety is common in primigravida mothers because they have never given birth, but in the era of the COVID-19 pandemic, psychological impacts and concerns occur in pregnant women which will trigger anxiety.
\end{abstract}

Keywords: Pregnancy, Anxiety, Primigravida, Multigravida, Covid-19 


\section{PENDAHULUAN}

Kecemasan merupakan reaksi emosional terhadap penilaian individu yang subyektif, dipengaruhi oleh alam bawah sadar dan tidak diketahui penyebabnya secara khusus. Kecemasan dapat timbul karena berbagai faktor yang menekan kehidupan diantaranya dalam menghadapi proses kehamilan.

Kehamilan adalah periode yang dihitung dari hari pertama haid terakhir (HPHT) hingga mulainya persalinan sejati, ini yang menandai awal periode antepartum. Periode antepartum dibagi menjadi tiga trimester yang masingmasing terdiri dari 13 minggu atau tiga bulan menurut hitungan kalender. Pembagian waktu ini diambil dariketentuan yang mempertimbangkan bahwa lama kehamilan diperkirakan kurang lebih 280 hari, 40 minggu, 10 bulan, atau 9 bulan sejak hari pertama haid terakhir (HPHT). Meskipun kehamilan adalah suatu proses alami namun kehamilandapat menimbulkan berbagai permasalahan baik permasalahan secara fisik maupun permasalahan psikologis. Permasalahan fisik dalam proses kehamilan, misal banyaknya usia ibu hamil yang terlalu muda atau usia yang sudah tua, terlihat dari hasil yang pernah dilakukan penelitian 2007 diperoleh ibu hamil dengan usia $<20$ sebanyak $8 \%$ dan ibu usia $>35$ th sebanyak $6,5 \%$, yang mempunyai riwayat hipertensi sebesar $21 \%$. Permasalahan yang terkait dengan psikologi adalah kecemasan yang timbul karena faktor kehamilan itu sendiri (internal) dan kecemasan yang timbul karena pengaruh lingkungan (eksternal). Terdapat berbagai faktor yang dapat mempengaruhi kecemasan selama kehamilan utamanya di era pandemic covid-19 yang akan menambah tingkat kecemasan ibu dalam menghadapi persalinan .

Di era pandemi covid -19 penyebaran wabah virus corona yang sangat cepat, melebihi kemampuan ilmuwan menciptakan vaksin dan obat yang efektif, memang mengkhawatirkan sehingga banyak orang mengalami kecemasan termasuk ibu hamil.

Kecemasan pada kehamilan merupakan reaksi emosional yang terjadi pada ibu hamil terkait dengan kekhawatiran ibu dengan kesejahteraan diri dan janinnya,keberlangsungan kehamilan, persalinan, masa setelah persalinan dan ketika telah berperan menjadi ibu, kecemasan pada kehamilan merupakan reaksi emosional yang terjadi pada ibu hamil terkait dengan kekhawatiran ibu dengan kesejahteraan diri dan janinnya,keberlangsungan kehamilan,persalinan, masa setelah persalinan dan ketika telah berperan menjadi ibu. 


\section{METODE}

Metode yang digunakan dalam penelitian ini adalah analitik dengan jenis desain penelitian eksperimental quasi Populasi dalam penelitian ini adalah ibu hamil trimester III di Puskesmas Bontobangun. Sampel dalam penelitian ini adalah ibu hamil trimester III (primigravida dan multigravida) berjumlah 25 orang baik kelompok kasus maupun control. Alat yang digunakan untuk pengambilan data adalah berupa kuesioner HARS ( Hemilton Rating Scale of Anxiety).

\section{HASIL}

Berdasarkan hasil penelitian pada tabel 1. Bahwa usia responden pada kelompok kasus sebagian besar masuk dalam kategori usia tidak beresiko yakni usia 20-30 tahun sebanyak 18 orang(72\%). Berdasarkan hasil penelitian pada tabel 2 . bahwa rata - rata usia responden pada kelompok intervensi yaitu 26.44 tahun dengan Standar deviasi 6.501, sedangkan pada kelompok kontrol yaitu 26.22 tahun dengan standar deviasi 5.523. Berat Badan pada kelompok intevensi rata - rata 63.68 dengan Standar Deviasi 8.905, sedangkan pada kelompok kontrol yaitu 57,56 dengan Standar Deviasi 2.622. Gestasi pada kelompok intevensi rata - rata 35.04 dengan Standar Deviasi 2.622 sedangkan pada kelompok kontrol yaitu 35.00 dengan Standar Deviasi 2.708. Paritas responden pada kelompok intervensi lebih banyak pada paritas Primigravida Yaitu yaitu sebeaar $52 \%$.

Berdasarkan hasil penelitian pada tabel 3. bahwa rata - rata nilai kecemasan pada kelompok sebelum dilakukan intervensi sebesar 14.60 atau derajat kecemasan ringan dengan standar deviasi 2.141, setelah intervensi mengalami penurunan dengan rata - rata 10.36 atau tidak ada kecemasan dengan standar deviasi 3.365. pada kelompok kontrol rata - rata score kecemasan sebesar 14.24 atau derajat kecemasan ringan dengan standar deviasi 1.363, setelah dilakukan pengukuran berikutnya tanpa intervensi didapatkan rata-rata score kecemasan 14.08 atau derajat kecemasan ringan dengan standar deviasi 1.525.

Berdasarkan Tabel 4. Tentang hasil Uji Statistik dengan menggunakan uji Independen $T$ Test didapatkan $P$ Value sebesar 0.000 . karna nilai $P$ Value $<0.05$ sehingga terdapat perbedaan rerata score derajat kecemasan bermakna pada kelompok intervensi dibangdingkan dengan kelompok control.

\section{PEMBAHASAN}

Usia yang optimal bagi seorang ibu untuk menjalani kehamilan adalah usia 20 sampai dengan 35 tahun, pada usia ini rahim mampu menerima kehamilan baik segi psikologik dan fisik sehingga aman dalam proses proses persalinan,sedangkan 
usia lebih dari 35 tahun dapat dikategorikan dalam resiko tinggi seorang ibu untuk menjalani kehamilan dikarenakan usia ini dapat menyebabkan kelainan bawaan serta adanya penyulit selama masa kehamilan dan persalinan. Usia ibu memiliki pengaruh penting terhadap perilaku kesehatan ibu hamil, khususnya pada ibu hamil trimester III.

Hal ini sesuai dengan teori yang dikemukakan oleh Handayani (2015), bahwa kemampuan seseorang dalam merespon kecemasan salah satunya dapat dipengaruhi oleh usia.Mekanisme koping yang baik lebih banyak diterapkan oleh seseorang dengan usia dan pola fikir yang matang dibandingkan dengan kelompok umur yang lebih muda. Kehamilan ibu dengan usia beresiko dapat menjadi penyebab rasa cemas ibu sebagaimana dalam teori yang menyatakan bahwa ibu hamil dengan usia beresiko dapat terjadi gangguan pada janin atau kelainan sehingga dapat menimbulkan rasa cemas terhadap ibu hamil terutama primigravida.

Berdasarkan hasil penelitian diatas, menunjukkan lebih dari setengah responden sebelum diberikan intervensi berada pada kondisi cemas, Setelah dilakukan intervensi sebagian besar tidak cemas dan berada pada cemas ringan. Pada tingkat tersebut, cemas terjadi pada kehidupan sehari-hari dan hanya dibutuhkan beberapa upaya untuk mencegah berbagai kemungkinan yang dapat terjadi. Kecemasan responden sebagian besar berada pada tingkat ringan dapat dikarenakan responden telah diberikan terapi dengan memberikan Relasksasi nafas dalam yang dapat memberikan manfaat untuk menghilngkan nyeri, memberikan ketentraman hati, dan berkurngnya rasa cemas.Relaksasi merupakan metode efektif mengurangi kecemasan. Sesuai dengan pernytaan Wiramihardja (2007) bahwa keteraturan dalam bernafas menyebabkan sikap mental dan badan menjadi rileks, sehingga dapat membantu mengurangi kecemasan pada ibu hamil.Teknik Relaksasi Nafas Dalam dapat meningkatkan ventilasi alveoli, memelihara pertukaran gas, mencegah atelektasi paru, mengurangi stress baik stress fisik maupun emosional.

Berdasarkan hal tersebut, dapat dinyatakan bahwa teknik Relaksasi Nafas Dalam efektif digunakan untuk mengurangi kecemasan termasuk kecemasan pada Ibu hamil. Selain itu, teknik ini dapat dijadikan alternatif pilihan pertama untuk mengurangi kecemasan pada ibu hamil dikarenakan langkah yang mudah diterapkan dan dapat dilakukan secara mandiri dan berkelanjutan dirumah apabila kecemasan

\section{KESIMPULAN DAN SARAN}

Kecemasan yang terjadi pada ibu hamil trimester III di era pandemic covid- 
19 banyak dialami oleh ibu hamil primigravida, sedangkan pada ibu hamil multigravida lebih banyak tidak mengalami kecemasan. Terdapat perbedaan kecemasan yang dialami ibu hamil trimester III pada primigravida dengan multigravida di era pandemic covid 19. Pandemi covid-19 diasumsikan tidak banyak berpengaruh terhadap terjadinya kecemasan pada ibu hamil trimester III, terbukti dengan hasil penelitian ini tidak beda dengan hasil penelitian disaat tidak terjadi pandemic covid-19.

Setelah mengetahui hasil penelitian ini diharapkan Perencanaan kehamilan/ persalinan sangat penting dilaksanakan pada usia 20-35 tahun, agar ibu merasa lebih siap untuk menghadapi kehamilan dan persalinan nanti tanpa ada rasa cemas yang dapat mempengaruhi kondisinya dan juga perkembangan janinnya. Selain itu sebaiknya ibu hamil mampu untuk mengatasi rasa cemasnya secara mandiri dengan cara kontrol pernafasan yang baik,melakukanrelaksasi, mengeluarkan semua keluhan kehamilan kepada suami/keluarga, pendekatan agama, pendekatan keluarga, dan senam hamil.

Untuk mengurangi kecemasan pada ibu hamil, lakukan pemahaman pemahaman tentang kehamilan dan persalinan, bahwa proses hamil dan melahirkan merupakan hal yang biasa bagi ibu yang berkeluarga. Beri penyuluhan untuk selalu menggunakan protocol kesehatan dalam kegiatan sehari-hari. Lakukan monitoring aktif melalui kegiatan posyandu ibu hamil.

\section{DAFTAR PUSTAKA}

Saifuddin, A. (2014). Buku Acuan Nasional Pelayanan Kesehatan Maternal dan Noenatal. Jakarta: Yayasan Bina Pustaka Sarwono Prawirohardjo.

Cunningham. (2016). Obstetri Williams. Jakarta: Penerbit Buku Kedokteran EGC.

Hawari, D. (2011). Manajemen Stres Cemas dan Depresi. Jakarta: FKUI.

Hidayat, A. A. (2017). Metodologi Penelitian Keperawatan dan kesehatan. Bandung: Salemba Medika.

Husin Farid. (2014). Asuhan Kehamilan Berbasis Bukti. jakarta: sagung seto.

Kemenkes. (2020). Kementrian Kesehatan Republik Indonesia.

Kemenkes. (2020). Pedoman Bagi Ibu Hamil, Ibu Nifas dan Bayi Baru lahir Selam Social Distancing. Kementrian Kesehatan Republik Indonesia.

Kusumawati, F., \& Hartono, Y. (2012).

Buku Ajar Keperawatan Jiwa. Jakarta: Salemba Medika. 
Pasaribu. (2014). Hubungan Paritas dan Usia Dengan Tingkat Kecemasan Ibu Hamil Trimester III Dalam Menghadapi Persalinan Di Puskesmas Sipea-Pea Kecamatan Sorkam Barat. . Jurnal Penelitian STIKES Nauli Husada Sibolga.

Prawirohardjo, S. (2014). Ilmu Kebidanan. Jakarta: Bina Pustaka.

Resmaniasih K, (2014). Pengaruh

Teknik Pernafasan Diagfragma Terhadap Kecemasan pada Ibu Hamil Trimester III (Doktoral Disertation Program Pasca Sarjana Undip)

Sadock, B. S. (2015). Kaplan \& Sadock's Synopsis of Psychiatry (11th ed.). Philadelphia: Wolters Kluwer.

Saifuddin, A. B. (2014). Buku Acuan Nasional Pelayanan Kesehatan Maternal dan Noenatal. Jakarta: Yayasan Bina Pustaka Sarwono Prawirohardjo.

Sugiyono. (2012). Metode Penelitian. Bandung: Alfabeta.

Videbeck, S. D. (2012). Buku Ajar Keperawatan Jiwa (Renata Komalasari). Jakarta: EGC.

WHO. (2016).

WHO. (2020). 
Tabel. 1. Distribusi Responden berdasarkan Umur

\begin{tabular}{lcccc}
\hline \multirow{2}{*}{ Umur } & \multicolumn{2}{c}{ Kasus } & \multicolumn{2}{c}{ Kontrol } \\
\cline { 2 - 5 } & $\mathbf{N}$ & $\boldsymbol{\%}$ & $\mathbf{N}$ & $\boldsymbol{\%}$ \\
\hline Beresiko $(<20$ dan $>35)$ & 7 & 28 & 4 & 16 \\
Tidak Berisiko $(20-35)$ & 18 & 72 & 21 & 84 \\
\hline Jumlah & $\mathbf{2 5}$ & $\mathbf{1 0 0}$ & $\mathbf{2 5}$ & $\mathbf{1 0 0}$ \\
\hline
\end{tabular}

Tabel 2. Distribusi Frekuensi Berdasarkan Karakteristik Responden di Puskesmas Bontobangun

\begin{tabular}{lcccc}
\hline \multicolumn{1}{c}{ Variabel } & \multicolumn{2}{c}{ Intervensi } & \multicolumn{2}{c}{ Kontrol } \\
\hline & Mean & $\begin{array}{c}\text { Standar } \\
\text { Deviasi }\end{array}$ & Mean & $\begin{array}{c}\text { Standar } \\
\text { Deviasi }\end{array}$ \\
\hline Usia & 26.44 & 6.501 & 26.20 & 5.523 \\
\hline Berat & 63.68 & 8.905 & 57.56 & 6.212 \\
Badan & & & & \\
\hline Gestasi & 35.04 & 2.622 & 35.00 & 2.708 \\
\hline Paritas & $\mathbf{N}$ & $\mathbf{\%}$ & $\mathbf{N}$ & $\mathbf{\%}$ \\
\hline Primigravida & 13 & 52 & 13 & 48 \\
\hline Multigravida & 12 & 48 & 12 & \\
\hline
\end{tabular}

Tabel 3. Hasil Analisis Univariat pada Kelompok Intervesi dan Kontrol di Puskesmas Bontobangun

\begin{tabular}{lcccc}
\hline \multicolumn{1}{c}{ Variabel } & \multicolumn{2}{c}{ Intervensi } & \multicolumn{2}{c}{ Kontrol } \\
& Mean & $\begin{array}{c}\text { Standar } \\
\text { Deviasi }\end{array}$ & Mean & Standar \\
& & 2.141 & 14.24 & Deviasi \\
\hline HRS-A Pre & 14.60 & 3.365 & 14.08 & 1.363 \\
\hline HRS-A Post & 10.36 & & & 1.525 \\
\hline
\end{tabular}

Tabel 4. Perbandingan Tingkat Kecemasan Primigravida dan Multigravida pada Kelompok Intervensi dan kontrol di Puskesmas Bontobangun

\begin{tabular}{|c|c|c|c|c|c|}
\hline \multirow[t]{2}{*}{ Variabel } & \multicolumn{2}{|c|}{ Intervensi } & \multicolumn{2}{|c|}{ Kontrol } & \multirow[b]{2}{*}{$P$ Value* } \\
\hline & Mean & $\begin{array}{l}\text { Standar } \\
\text { Deviasi }\end{array}$ & Mean & $\begin{array}{l}\text { Standar } \\
\text { Deviasi }\end{array}$ & \\
\hline HRS-A Pre & 14.60 & 2.141 & 14.24 & 1.363 & \\
\hline HRS-A Post & 10.36 & 3.365 & 14.08 & 1.525 & 0.000 \\
\hline
\end{tabular}

